\title{
Litographic Publications Of Khiva Khanate
}

\author{
M.M.Matyakubova, D.R. Atamurotova \\ Urgench State University, Urgench, Uzbekistan. \\ E-mail: matyakubova1979.mm@gmail.com \\ E-mail: atamuratovadilafruz@gmail.com
}

Article History: Received:11 January 2021; Accepted: 27 February 2021; Published online: 5 April 2021

Abstract: The article is dedicated to the issue of the lithographic publications of Khiva khanate at the end of the $19^{\text {th }}$ and the beginning of the $20^{\text {th }}$ centuries. The main attention is paid to the works of great writers and poets which were published in lithographies of Khiva khanate during that period. Also, the ideas in the article were proven by the facts mentioned in the works of historians

Key words: lithography, publication, stone print, Khiva, divan, bayaz.

\section{Introduction}

The method of lithographic book printing, that is, the printing of handwritten text with the help of specially processed, limed stone with a separate ink, was common in many eastern countries.

In the $19^{\text {th }}$ century, literary life in Khiva and Kokand khanates was more lively than ever, and Arabiclanguage works came from Turkey, Iran, and India. In Russia (Kazan, Orenburg, Baku, Bokhchasaroy) printed materials using Arabic fonts were not circulated in Central Asia. In the Central Asian region, local lithography appeared in the last quarter of the $19^{\text {th }}$ century.

Researcher R. Mahmudova notes that lithographic book printing has become a new stage in the popularization of books in Central Asia. Handwritten books were created over the years and became expensive, so they could not be the property of a wide readership. It was in the cultural life of Turkestan that a new method of publishing - lithography became popular [12,3].

The first lithographic printing house in Turkestan - lithography was established at the initiative of Khiva khan Muhammad Rahimkhan II Feruz.

According to researcher F. Ernazarov, the stone machine was brought to Khiva by Feruz from Geneva [4, 19]. Some reports indicate that it was brought from Iran. The first edition of the Khiva lithography was made in $1874[24,58]$.

Ibrahim Sultan, an Iranian special printer, began his first work in lithography and was the first to print in lithography. Ibrahim Sultan took Otajon Abdalov as an apprentice when he found it difficult to work alone in the newly formed stone. Otajon Abdalov worked here for five years as a student and then as a full-time printer. O. Abdalv himself mentioned this, that is, his first four years of service in the lithographic printing house were apprenticeship, and later he began to work independently. Initially, some documents were published in lithography. After Ibrahim Sultan left for Iran, Otajon Abdalov was responsible for all the work on the stone.

According to A.N. Samoilovich, the stone print was moved to Tozabogh in 1908 in the field yard of Muhammad Rahimkhan [20, 82]. Some of the books published by the palace printing house are stamped "Khurshid". Otajon Abdalov, the first master of the Khurshid lithographic printing house in Khiva, noted that the lithography was founded in 1874 , on the $50^{\text {th }}$ anniversary of the lithography [8]. Thousands of lithographic books published in printing houses had more than forty titles, literary, artistic and religious [17, 100-102].

With the launch of lithography in Khiva, the printing of books was revived, and there was an opportunity to publish many copies of classical literature and immortal samples of history.

The study of the history of Central Asian lithography begins with the orientalist, Professor A.A. Semyonov. In 1912 he created the first manuscript catalog of lithographs under the auspices of the Turkestan People's Library. A.A. Semyonov points to the extreme "rarity" of books published by Khiva lithography, in which E.K. Betger also compares the works published in his research to "precious gems" [3, 77-78]. There was a specific reason for this, of course, that the printing house of the khan's palace did not operate for purely economic purposes, that is, the published books were not sold. Because the khan gave books as gifts to his officials or relatives, the books that were published immediately became rare. The initial circulation was 150 200 copies.

The history of Khiva printing, writing and calligraphy in the pre-printing period, the art of books, the type of ink, paper required for this field, the style of writing letters, the emergence of printing and its role in the cultural environment of the khanate were studied.

The masters of Khiva palace lithography initially began to publish books on local paper, but due to the fact that the paper did not accept the paint well, they continued to publish on Russian papers [5, 323]. The compositions of the title page were varied. In many cases, the orange (rhombus) ornament appears on the title page of the book. In some books, an oval-shaped ornament consisting of twisted horns or flowers with leaves is 
found. The books are usually placed in a green leather case [5, 326-327]. According to A.N. Samoilovich, the stone print was moved to Tozabogh in 1908 in the field yard of Muhammad Rahimkhan. It was headed by Khudaibergan Muhrkan at that time [9]. A.N. Samoilovich studied the work of the lithograph - the khan's printing house was working in the central chordara of the Tozabogh garden, occupying the sunny side of the chordara. The work to be printed comes down to a room where the calligrapher copies it with lithographic ink. In another room, the copy is dropped page by page on the stone and traces of the copy are taken from it. Today's stone can hold four pages, while the previous one could hold only one. The printing press is moved manually, with two workers standing in front of it: one rotates the wheel, and the other rotates the pages. A third worker spins the paint on a separate table [20,82]. According to A.S. Samoilovich, the khan's library in Tozabogh contained about 200 manuscripts and many books on Turkestan, Kazan, Ottoman Turkish, Persian and Indian editions [20, 74-79]. It is known that the khan's library contains not only Khiva lithographic editions, but also other foreign lithographic editions.

Most of the books on the Khiva printing house, which are now in the fund of the Institute of Oriental Studies of the Uzbek Academy of Sciences, are divans, which are divans of Alisher Navoi, Munis Khorezmi, Muhammad Roji and Khiva poets of the late $19^{\text {th }}$ and early $20^{\text {th }}$ centuries. Navoi's "Khamsa" and "Khazoin ulMaoniy" were published under the editorship of Muhammadrasul Mirzaboshi. Initially, Navoi's "Khamsa", Munis's "Devoni Munis", Agahi's "Devoni Ogahi", Feruz's "Devoni Feruz", as well as divans and bayazs of such talented poets as Kamil Khorezmi, Muhammad Yusuf Bayoniy, Ahmadjon Tabibiy, Muhammadrasul Mirzo were published in the lithography [1, 97]. E.K. Betger and G.N. Chabrov [16, 65] noted that the first book published in the Khiva palace lithograph in 1880 was Alisher Navoi's "Khamsa". E.K. Betger traces the activity of Khiva lithography in 1880, based on the works "Khamsa", "Devoni Munis", "Devoni Rojiy" kept in the State Library of the USSR named after A.Navoi in the 40s of the last century. T.N. Kari-Niyazi also, based on the data of E.K. Betger, states that the year of publication of the first centuries was 1880. However, in the research of P.M. Melioransky and V.V. Bartold, they give information about the founding of lithography in 1874 [11, 415], but do not cover any information about the first printed work published in this printing house, although their research had enough information about it. In addition, A. Vamberi, who was in the khanate in 1863 , published an article in 1892 [23, 193-208; 269-291], which included excerpts from "Devoni Munis" with Arabic graphics and verses translated into German. The article contains excerpts from "Devoni Amir" and "Devoni Munis". Another source of information about the first printed book published in lithography was an article written by A.N. Samoilovich during his visit to Khiva in 1908, but remained in manuscript until the end [22]. A. Vamberi's article did not reach Central Asia at that time, and the first book was considered to have been published in 1880 until the 70 s of the $20^{\text {th }}$ century. G.N. Chabrov also conducted research on this issue, but could not come up with concrete solutions. We see a shift in this area in M. Rustamov, who in his research provides information about the version of "Devoni Roji" published in 1879 [19]. Finally, in 1971, R. Mahmudova provided information that the first book was "Nisab us-Sibiyon" by Abu Nasri Farrohi, published in 1876 [12]. Research based on the data of A. Vamberi and A.N. Samoilovich showed that the first published work was Shermuhammad Munis's "Devoni Munis". The second edition of the work was made in 1876, and the third edition in 1879 [7, 263]. The book is written in Uzbek and consists of 668 pages. This work is kept in the library of Khiva khan. In 1880, the collection "Devoni Kholis" by Yaqubhoja ibn Ibrahimhoja was published. This divan includes gazelles, rubais (quatrains) and muhammas of the poet Kholis. The work is published with a three-page preface by Kamil Khorezmi. In the same year, 1880, after the publication of the epic "Hayrat ulabror" from "Khamsa" of Alisher Navoi, in 1882, Alisher Navoi's "Khazoin ul-maoniy" [6, 104], known among the people as "Chahor devon", consisting of 50,000 lines, was published. Prepared for publication by Ibrahim Sultan with Khorezmi's foreword. This work entered the history of printing as the only complete work. In 1882, Kamil Khorezmi prepared Fuzuli's "Devoni Fuzuli Baghdadi" for publication. This work became the first printed book of Fuzuli [2, 385]. Also, in 1882, the Khiva historian, translator, poet and statesman Muhammadrizo Erniyozbek oglu Agahi published a 530-page book entitled "Taviz ul-oshiqin" (Amulet of Lovers) [6, 103]. We currently have two editions of this work. The first edition was made in 1882, and the second edition in 1905. Four editions of Kamil Khorezmi's divan are also known. From 1880 to 1881 it was published under the title "Devoni Komil", and the rest of the editions were made in 1895 and 1905.

In 1897, Feruz's poems were included in the collection "Devoni Feruz" and published under the title of Kamil Khorezmi. Also, the "Complex of Divans" was published four times, with samples of works by poets published by Muhammad Rahimkhan II Feruz. All publications are in Uzbek, differing only in size and in part in the fact that the poems of the authors are presented in a different order. The first edition was published in 1906 with 598 pages, the second edition in 1907 with 451 pages, the third edition in 1908 with 898 pages, and the fourth edition in 1909 with 1192 pagesn [14, 28]. All publications of this divan are currently kept at the Institute of Oriental Studies of the Academy of Sciences of Uzbekistan.

Along with Otajon Abdalov, Muhammad and Khudaibergan Harrot, Khudaybergan Muhrkan, Ismail Devon, Komil Devon, Madrahim Saidashev and others worked in Khiva printing house. 
The Khiva lithograph differs from other lithographs in Central Asia in that it was unveiled at the palace of Muhammad Rahimkhan II Feruz, which has been engaged in the reproduction of manuscripts, a unique cultural heritage of the people that have been cherished for centuries. The publishing house publishes books mainly in Uzbek. The main task of the lithograph was to increase the number of published manuscripts, to publish the works and translations copied by calligraphers for years, and to present them to the public in a short period of time. Khan of Khiva Muhammad Rahimkhan II Feruz regularly got acquainted with the activities of this publishing house and initiated the publication of works by poets, historians, translators Munis, Agahi, Tabibi, Bayoniy, who played an important role in the literary history of the khanate. As a cultural leader, Feruz highly valued the scholars of his time. Perhaps that is why his divan was published later than the works of other thinkers [13].

Poems by Bayoniy, Agahi, Pirkomil, Mirzo, Raji, Tabibi, Kamil Khorezmi, Kamil Devoni, Gulami, Sultani, Saadi Asad, Ghaziy were also published during the studied period. Among them, Ahmadjon Tabibi's "Majmuat ush-shuaro (Collection of Poets)" was published in 1909 by Feruz's order. This huge complex is 1600 pages long and contains 3099 gazelles. The complex acquaints with the life, activity and works of more than 30 poets working in the literary environment of Khorezm. Ahmadjon Tabibi wrote a seven-page preface to the work. Tabibi first wrote the epic "Vomiq and Azro" in Uzbek in 1910, the work was published several times in lithography. Chapter 81 consisted of 1620 verses [18,99]. Ahmadjon Tabibi also arranged several divans in Uzbek and Persian and published such divans in 1909-1910 as "Hayrat ul-ushshak", "Munis ul-ushshak" and "Meroj ul-ushshak". According to the palace poet Laffasi, a great representative of Khiva's literary environment, Khiva khan Feruz also compiled a collection called "Seven Princes". This collection was published four times in Khiva lithography between 1906-1909 [2, 386]. Feruz also called the collection as "Haft Shuaro", in which he gave examples of the work of his brothers and nephews $[6,103]$. This collection was prepared for publication by Kamil Devoniy. In the books of Khiva in those years there were also works translated from other languages, including from Tajik into Uzbek, and they also took a worthy place in the treasury of the Khiva library.

At the end of the $19^{\text {th }}$ and the beginning of the $20^{\text {th }}$ centuries, translated works were published in Khiva. For example, Muhammadrasul Mirzo translated Baghdadi's "Soqiynoma" or "Haft Jom" from Tajik into Uzbek in the Masnavi genre and this work was published twice in 1907-1908 with the addition of "Devoni haft shuaro", and in 1909 with the addition of "Devoni Mirzo". Another book published in the Khiva printing house in the early $20^{\text {th }}$ century is Muhammad Khivaqi's "Muntahab ul-lughat". In a short period of time, the works of more than 30 poets and translators, who took part in the Khiva literary environment, were published in the Khiva lithography. The hard work that secretaries and calligraphers have done over the years has come to an end. But this did not stop the tradition of copying works by hand. Calligraphers, the owners of calligraphy, also continued to write rare works, that is, manuscripts were created with lithographs, and they were found in khan's libraries and private libraries.

It should be noted that Muhammadrasul Mirza played a special role in the development of lithography, in the publication of rare, priceless books, translations, bayazs and divans. Muhammad Rahimkhan II Feruz entrusted the preparation and publication of extremely rare and large works only to Muhammadrasul Mirza. He was also responsible for the work of the lithography under the khan's palace, publishing and control. Mirzo carefully examined the manuscripts submitted for publication, selected and reviewed them himself, and recopied some of the works. Therefore, in many lithographs one can find the preface of Muhammad Rasul Mirza. In particular, in 1880, with the three-page preface of Kamil Khorezmi, the collection "Devoni Kholis" by Yakubkhoja ibn Ibrahimkhoja Kholis was published [2, 385]. His contemporaries write about Mirza: "Muhammadrasul Mirza was not only a famous musician, but also a composer. He was also a unique calligrapher and wrote beautifully in his naskh and taliq methods. He has taught more than 400 people the art of calligraphy. On the instructions of Muhammad Rahimkhan and Asfandiyarkhan, Mirzo copied several dozen books" [15].

If we look again at the works published under the guidance of the enlightened khan, the patron of culture, most of these works consisted of bayoz, divan and translations.

Researcher A. Mirzarahimov lists some works published at the initiative of Muhammad Rahimkhan II Feruz as follows:

Muhammad Rahimkhan II Feruz from 1879 to 1906 Alisher Navoi's “Khamsa”, "Devoni Feruz” (1880), Muhammad Yusuf Mahdum's "Devoni Rojiy” (1879), "Devoni Kholis” (1880), "Chor Kitab” (1880)), "Chahor Devon", "Devoni Komil”, Muhammad Rahim II Feruz's "Devon”, "Badoe' al-vasat” (1881, 1882), "Gharayib us-sighar" (1881), translation of "Navadir al-Shabab" (1881), "Devoni Fuzuli" (1882), "Devoni Bedil” (1883, with the rubai of Umar Khayyam), "Fiqhi Kaydani ma'a sharhuh" from Arabic by Muhammadrasul Akhund and Mufti ibn Shermuhammad. He published such works as "Devoni Kamil" (second edition), "Devoni Ogahiy", "Devoni Bayoniy", "Majmuat ush shuaroi Feruzshahi" (including 30 poets) [14, 42]. We continue this list with Ali Safi's "Rashahotu ul-Hayat" (1890) and Lutfullo Nasafi's "Sharh" and "Tarjimai Fiqhi Kaydani Musammi ba Targir ul Musammin" (1890) as "Devoni Sultani" (1890). 1906, 1907, 1908), "Devoni Sanoyi” (1909), "Devoni Sadiq" (1906, 1918), "Devoni Tabibiy" (1909, 1910), "Hayrat ul-ashiqin" (1910). ), "Devoni Akil" 
(1906), “Devoni Gujji” (1907, 1908, 1909), “Devoni Farrukh” (1906), “Devoni Nazir” (1907, 1909), “Zayn alArabic" (1911), "Mazhar al-ishtiyaq" (1909).

The lithography of the Khiva palace lasted until 1910, i.e. until the death of Muhammad Rahimkhan. Isfandiyarkhan was not interested in the activity of lithography. No Khiva edition is mentioned in the bibliographic descriptions of the literature published in Turkestan from October 10, 1910 to February 26, 1911 [25, 144]. It is known from history that on February 2, 1920 in Khiva the last Khiva khan Said Abdullakhan was overthrown and new Khorezm People's Soviet Republic was established. This newly formed government began to make effective use of the lithography service to disseminate its notices and announcements to the public. At the initiative of Otajon Abdalov, on March 8, 1920, the first newspaper "inqilob quyoshi (Revolution Sun)" was published. This printing house also took a leading position in the printing of paper money of the new republic. During this period, Otajon Abdalov also made a significant contribution to the development of lithography in Khorezm. He prepared apprentices like Ota Miskinov. He was also a good chemist. He also made color editions of special color and ink mixtures for printing newspapers, magazines, and books on lithography. The immortalization of the name of the first Uzbek printer Otajon Abdalov, the holding of scientific and theoretical conferences in the places where he was born and served, and the naming of the printing house of the regional newspaper "Khorezm Haqiqati (Truth of Khorezm)" Otajon Abdalov are an example of respect for the first printer. At a time when the creation of lithographs was developing, the writing of manuscripts did not stop. The calligraphers continued to copy many bayazs, divans and translated works by the khan's order in beautiful calligraphy. That is, during this period, along with the activities of the lithographer, the work of the calligraphers continued.

\section{Conclusion}

The books published in the Khiva lithograph became popular among the people, inspired by the cultural and enlightenment growth of the population, inspired the creation of new works by scholars and writers, and replenished the looted khan's library. The establishment of the Khiva lithography did not preclude the copying of manuscripts. Rare manuscripts, historical works, translations, bayozs and divans were copied by Khiva calligraphers during this period as well. The significant role and contribution of Muhammad Rahimkhan II Feruz in the increase of manuscripts and lithographs created in the Khiva khanate should be acknowledged. The literary atmosphere created by Muhammad Rahimkhan II flourished in the valley of the Khiva khanate during the years of political crisis.

1. Abdurasulov A. Khiva. - P. 97.

\section{References}

2. Ahunjanov E. Kutubkhonashunoslik, arkhivshunoslik, kitobshunoslik nazariyasi va tarikhi. Tafakkur Bostoni, - T., 2011. - P. 385.

3. Betger Y.K. Iz istorii knijnogo dela $\mathrm{v}$ Uzbekistane (k 70-letiyu poyavleniya pervoy uzbekskoy litografirovannoy knigi)//Izvestiya AN Uz SSR, 1951. -№2. - P. 77-78.

4. Chabrov G.N. U istokov uzbekskoy poligrafii // Sos.Uzbekistan. 1956.№ 12. - P. 19.

5. Chabrov G.N. U istokov uzbekskoy poligrafii (khivinskaya pridvornaya litografiya 1874-1910) // Book. Issledovaniya i materialy. Collection. Part IV. - M.: Nauka, 1961. - P. 326-327.

6. Davlatyor Rakhim, Shikhnazar Matrasul. Feruz shoh va shoir qismati. - P. 104.

7. Hasaniy S. Khorazm marifati olam kozgusi. - P. 263.

8. Inqilob quyoshi. 1924, №16.

9. Khorazm haqiqati, №28, 1965.

10. Makhmudova R. Litografirovannye proizvedeniya i ikh znachenie $\mathrm{v}$ istorii uzbekskoy literatury (konec XIX - nachalo XX v.). Abstract of diss. of cand. of philol. sciences. - Tashkent: AN Uz SSR, Institute of Oriental Studies named after Abu Reyhan Beruniy, 1971. - P. 3.

11. Melioranskiy P.M. Tureckie narechiya i literatura // Encyclopedic dictionary of F.A. Brokgauz and I.A. Efron. - SPb., 1902. Volume 67. - P. 163; Bartold V.V. Istoriya kulturnoy jizni Turkestana // Essays. - M., 1963. Part 1. - P. 415.

12. Makhmudova R. Litografirovannie proizvedeniya i ikh znachenie v istorii literatury (konca XIX - nachalo XX v.): Abstract of diss. of cand. of philol sciences. - Tashkent, 1971.

13. Matyakubova M.M. XIX asrning ikkinchi yarmi - XX asrning boshlarida Khiva khonligida kitobat va kutubkhona tarikhi. - Urganch. 2008.

14. Mirzarahimov A. Khorazmda ilk nashrlar // Moziydan sado. 2007. -№1 . - P. 28.

15. Mulla Bekjon Rahmon oghli., Muhammad Yusuf Bayoniy. Khorazm musiqiy tarikhchisi. - Khiva, 1925. P. 42.

16. Osmanova M.N. Staropechatnaya kniga v Sredney Azii v konce XIX - nachale XX v. History and archeology of the Caucasus. 2013. - P. 65.

17. Ozbekistonda ijtimoiy fanlar. 1974. -№7. - P. 100-102.

18. Qobulov N. Khorazm adabiy muhiti. - Khorazm. Urganch, 1992. - P. 99. 
19. Rustamov M. Istoriya knigi i knijnogo dela v Sredney Azii (vtoraya polovina XIX - pervaya chetvert XX veka): Abstract of diss. of cand. of philol sciences. - Tashkent, 1968.

20. Samoilovich A.N. Khivinskie pridvornoe knigokhranilisha i knigopechatinya. Izvestiya AN Turkmenskoy SSR. Seriya obshestvennix nauk. 1981, -№1, - P. 82.

21. Samoilovich A. Khivinskoe pridvornoe knigokhranilisha i knigopechataniiya // Manuscript. (prepared for the sphere of social sciences of TurkAS). 1981. - P. 74-79.

22. Samoilovich A.H. Khivinskie pridvornie knigokhranilisha i knigopechatnya // National Library of Russia. Department F. 671. -№145.

23. Vambery N. Zwei modem centralasistusche Dichter, Munis und Emir // WZKM. 1892. Bd. VI. - P. 193208, 269-291.

24. Yazberdiev A. K voprosu o nachalnom periode knigoizdatelskoy deyatelnosti Khivinskoy litografii (18741880). Izvestiya AN Turkmenskoy SSR. Seriya obshestvennykh nauk. 1971, №4. - P. 58.

25. Zimin L. Bibliografiya. Srednyaya Aziya. Yejemesyachnoe literaturno-istoricheskoe izdanie. 1911. - P. 144. 